12. Krestiashin, V.M., Tarasov N.I. and Shliapnikova N.S. Pediatric Surgery. $2007 ; 6: 46-49$ [in Russian].

13. Vissarionov S.V., Drozdetskiy V.P., Pozdnikin Yu.I. Metod khirurgicheskogo lecheniia idiopaticheskogo skolioza poiasnichnogo otdela pozvonochnika u detey : metod. posobiye [Method of Surgical Treatment of Idiopathic Scoliosis of Spine Lumbar Part in the Children: Method. Manual]. Sankt-Peterburg ; $2010: 19$ p. [in Russian].

14. Lukash A., Shubina Ye., Belianchikova N. Skolioz izlechim Profilaktika i lecheniye ortopedicheskikh problem u detey [Scoliosis is Curable! Prevention and Treatment of the Orthopedic Problems in the Children]. SanktPeterburg : Nauka i Tekhnika ; 2008 : 272 p. [in Russian].

15. Vasilyeva N. and Okhotnikova N. Doshkolnoye vospitaniye. $2010 ; 2$ : 35-38 [in Russian].

16. Nalchadzhian A.A. Psikhologicheskaia adaptatsiia: mekhanizmy i strategii [Psychological Adaptation : Mechanisms and Strategy]. Moscow : Eksmo; 2009 : 368 p. [in Russian].

17. Ivanov A.B., Belinskaia A.B., Volfman M.V. et al. Sotsialnaia pedagogika : ucheb. posobiye [Social Pedagogy: Educ. Manual]. Moscow : Dashkov i Ko ; 2010 : 424 p. [in Russian].

18. Kaminska O.V. Problema sotsialno-psykholohichnoi dezaptatsii ditei z osoblyvymy potrebamy [Problem of Social-andPsychological Disadaptation in the Children with Special Needs]. In : Aktualni problemy navchannia ta vykhovannia liudei z osoblyvymy potrebamy: zb. nauk. pr. [Actual Problems of the Education of the Children with Special Needs: Coll. Sci. Works]. Kyiv ; 2007 ; 2 (4). URL http://ap.uu.edu.ua/article/582 [in Ukrainian].

19. Dandy J., Cullen C.

Educational Psychology. 2007 ; 8 : 1013-1014.

20. Grishyna, L.P., Lavrova D.Y. Mediko-sotsyalnaya ekspertiza $i$ reabilitatsiia. 2006 ; 2 : 27-30 [in Russian].

21. Bartrshyn Y.T. Khirurhiia pozvonochnika. 2006 ; 4 : 84-93 [in Russian].

22. Grebova L.P. Lechebnaia fizicheskaia kultura pri narusheniiakh oporno-dvigatelnogo apparata u detey i podrostkov [Exercise Therapy at Locomotor System Disorders in Children and Adolescents]. Moscow : Akademiia ; 2006 : 115 p. [in Russian].

Надійшла до редакції 12.09.2016

\title{
ANALYSIS OF CONDITIONS AND NATURE OF SUBWAY TRAIN DRIVERS' LABOUR
} Dumka I.V.

\section{АНАЛПЗ УМОВ ТА ХАРАКТЕРУ ПРАДШ МАШИННСТІВ Е.}

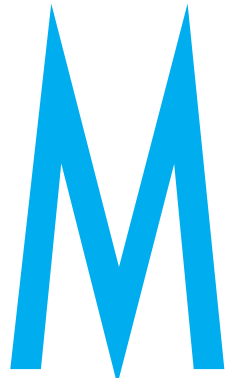

ДУМКА І.В.

ДП «Український медичний центр безпеки

дорожнього руху та інформаційних технологій

МОЗ України», м. Київ

удк 613.6.02 : $629.431 / 432$

Ключові слова: машиністи електропоїздів метрополітену, шкідливі умови праці,

патологічні процеси. етрополітен - швидкий, зручний і надійний вид транспорту, який вирізняється високими швидкостями, регулярністю руху поїздів і великою кількістю пасажироперевезень (до 60 тисяч пасажирів на годину в одному напрямку).

Нині робота машиністів електропоїздів (МЕП) метрополітену є однією з найвідповідальніших серед багатьох професій. Це пов'язане з тим, що працівники даної категорії забезпечують безпеку руху метрополітену, несуть відповідальність за життя великої кількості пасажирів. Трудовий процес МЕП полягає у керуванні поїздом, контролем над посадкою і висадкою пасажирів на станціях та станом обладнання. Керування поїздом здійснюється одним машиністом. Професійний відбір претендентів на професію МЕП здійснюється досить жорстко згідно з наказом Міністерства транспорту та зв'язку України від 29.04.2010 р. № 240 «Про затвердження Порядку проведення медичних оглядів працівників певних категорій залізничного транспорту, метрополітенів та підприємств міжгалузевого промислового залізничного транспорту України». До цієї професії допускаються практично цілком здорові люди. Але у процесі роботи у цього контингенту працівників можуть розвинутися різні захворювання, які у кінцевому результаті можуть призвести до втрати їхньої професійної придатності.

Робочим місцем МЕП $є$ кабіна електропоїзду з кріслом, дошкою приладів, пультами та важелями керування. Інформаційний зв'язок з диспетчером залізничної станції ведеться радіоканалами. Машиніст щогодини сприймає сигнальні подразники, які розподіляють на зовнішні та внутрішні сигнали з пульту керування. Джерелом зовнішніх сигналів $€$ світлофори, розташування стрілок на станціях, платформи та різні ситуації, інформація про які надходить

АНАЛИЗ УСЛОВИЙ И ХАРАКТЕРА ТРУДА МАШИНИСТОВ ЭЛЕКТРОПОЕЗДОВ МЕТРОПОЛИТЕНА

Думка И.В.

ГП «Украинский медицинский центр безопасности дорожного движения и информационных технологий Минздрава Украины», г. Киев

В статье представлены вопросы влияния неблагоприятных факторов производственной среды на организм машинистов электропоездов метрополитена. Среди неблагоприятных производственных факторов основными являются шум и вибрация, нервно-эмоциональное перенапряжение, стрессы, вынужденная рабочая поза, гиподинамия, неблагоприятный микроклимат, полное или частичное отсутствие естественного освещения, резкие перепады освещения. Эти факторы наиболее достоверно приводят к срыву механизмов адаптации и возникновению патологических отклонений от нормы у машинистов электропоездов.

Заболеваемость машинистов электропоездов метрополитена требует дальнейшего изучения и решения вопросов улучшения условий труда, разработки мероприятий профилактики и коррекции выявленных патологических отклонений и заболеваний внутренних органов.

Ключевые слова: машинисты электропоездов метрополитена, вредные условия труда, патологические процессы. 
через спостереження у дзеркало заднього огляду, сигнали попередження, люди та сторонні предмети на шляху тощо. Пульт керування електропоїздом містить низку джерел інформації: сигналізація щодо стану потягу, вказівник ступенів переключення режимів роботи двигуна (автомат-контроль-переключення), аварійна сигналізація.

Робота МЕП має усі характерні ознаки операторської праці належить до категорії робіт з високою нервово-емоційною напруженістю [1]. Складність поєднання особливостей роботи в умовах підземних споруд метрополітену (тунелях), інтенсивності пасажиропотоків сучасного мегаполісу та специфічних умов праці (шум, вібрація, несприятливий мікроклімат, інфразвук, повна або часткова відсутність освітленості, різка зміна штучного та природного освітлення, вимушена робоча поза тощо) вимагає від машиніста належної професійної підготовки, стабільного психофізіологічного стану, збалансованості центральної нервової системи для безперервного виконання усіх правил, інструкцій, вказівок диспетчерів, прийняття єдино правильних та швидких рішень в екстремальних ситуаціях [2, 3]. Машиніст повинен постійно підтримувати увагу на високому рівні, швидко приймати точні й безпомилкові рішення за наявності дефіциту часу, безперервно одержувати інформацію, що надходить, і завжди бути готовим до своєчасних і правильних дій в екстрених ситуаціях. МЕП повинні прогнозувати свої дії, планувати зупинку потягу у точно визначеному місці. Потрібно також оцінювати відстань до місця зупинки та точно визначати час і місце передбаченого графіком початку гальмування для зміни швидкості руху поїзда тощо $[4,5]$. Робота відбувається в умовах жорсткого графіка руху, усі штатні ситуації чітко прописані у посадовій інструкції, необхідно ретельно дотримуватися цих вказівок, циклічності й одноманітності виконуваних операцій в умовах коротких проміжків часу (під'їзд до станції 3 одночасним гальмуванням, зупинка поїзда, відкриття дверей, висадкапосадка пасажирів, відкриттязакриття дверей 3 обов'язковим візуальним контролем, розгін і рух). Під час руху необхідно слідкувати за показниками приладів, отримувати інформацію по радіозв'язку, від дорожніх знаків, включати радіооголошення про наступні станції та попередження про зачинення дверей, слідкува- ти за ремонтними роботами у тунелях під час руху поїздів, попереджати ремонтників про наближення поїзда звуковим сигналом У нештатних ситуаціях машиніст зобов'язаний приймати рішення в умовах дефіциту часу, при цьому відповідальність за безпеку життя пасажирів лежить на ньому. Потрібно пам'ятати та за необхідності діяти за великою кількістю правил та посадових інструкцій, у разі порушення яких існує загроза матеріальної або юридичної відповідальності. Кожна дія машиніста надзвичайно відповідальна, тому що будьяка груба помилка у діяльності може мати найтяжчі наслідки.

Праця машиніста електропоїзда пов'язана з тривалим виконанням однотипних простих операцій у заданому темпі, що супроводжується постійною концентрацією уваги в умовах малого обсягу професійно значимої інформації, що, як правило, викликає розвиток стану «монотонії». Монотонність роботи сама по собі $є$ гальмівним чинником, що викликає сонливість [6-8]. У рейсах, крім зорових монотонних подразників, на МЕП додатково впливають постійний шум і вібрація, які сприяють швидкому розвитку стомлення та негативних змін загального функціонального стану організму, а також знижують слухову чутливість та гостроту зору, тобто викликають погіршення ясного бачення [6-8]. Також додатково діють чинники уповільнення рухових реакцій та гіподинамія (сидяча поза, малий обсяг професійно необхідних рухів), а також неоптимальний тепловий режим кабіни машиніста. Причиною виникнення цього стану $є$ не тільки монотонна праця (пов'язана з автоматизацією деяких систем керування), але й низка інших факторів: необхідність підтримки постійної готовності до активної діяльності, необхідність тривалого збереження вимушеної пози, обмеження рухової активності, шум, вібрація, особливі умови освітлення та несприятливий мікроклімат кабіни.

Особливий відбиток накладає перебування у підземних спорудах (тунелях). Машиніст перебуває у кабіні один, постійно присутня нервово-емоційна напруга у зв'язку з відповідальністю за пасажирів у вагонах, що сягає межі у позаштатних і аварійних ситуаціях, а також під час зупинок електропоїзда у тунелі. У години «пік», коли інтервал руху електропоїздів менше однієї хвилини, а кількість пасажирів гранично можлива (пасажири ледве вміщаються на платформі, неможливо зачинити двері й необхідно ретельно дотримуватися графіка руху), машиніст практично перебуває у стані стресу.

Слід відзначити нерегулярність робочих змін. Існує вісім змін, які починаються о четвертій годин ранку й закінчуються о другій годині ночі. Тривалість зосередженого спостереження у машиністів становить до 60\% часу зміни, щільність світлових та звукових сигналів у середньому на годину роботи близько 750. На МЕП впливає дія великих перепадів яскравості світла під час виїзду на наземні станції, а також коливання рівнів освітленості при проходженні електропоїзда тунелем, різка зміна штучної та природної освітленості. Це негативно позначається на емоційному стані, діяльності аналізаторів, біоритмах МЕП, що проявляється у порушенні тривалості і фаз сну і, як наслідок, у порушенні нормального перебігу фізіологічних процесів [9-12]. Навіть професійно відібраний і добре підготований протягом багатьох років фахівець, працюючи на межі своїх можливостей, нерідко припускається непрогнозованих та важкозрозумілих відхилень від прописаного алгоритму діяльності [13]. У зв'язку з цим необхідні систематичний аналіз та посилення контролю над надійністю машиністів, у т.ч. 3 тривалим професійним стажем (5-10 років і більше). Діяльність МЕП здійснюється в умовах постійного замкнутого простору кабіни електропоїзду. у таких умовах він зазнає дії шуму, вібрації, неіонізуючого випромінювання, електромагнітного поля та несприятливих метеорологічних умов. Основними джерелами шуму $\epsilon$ рухомі частини електропоїзда. Вертикальне і горизонтальне покачування кузова стають джерелом низькочастотної і високочастотної вібрації. Низькочастотні компоненти відповідають власним покачуванням кабіни, високочастотні зумовлені вібрацією коліс через ресорну систему і систему опору кузова на ходову частину, а також впливом вібрації силових установок [14].

МЕП властива певна гіподинамія. Має місце вимушена робоча поза. На електропоїздах $€$ слабкі електромагнітні поля. Параметри штучного освітлення не завжди відповідають санітарногігієнічним вимогам $[6,15]$.

За даними багатьох авторів, негативним фактором виробничого середовища МЕП є вібрація. Джерелами вібрації на електропоїздах $є$ рухові установки та інші механізми. Частота та амплітуда вібрації визначаються багатьма факторами: типом електропоїз- 
natural lighting, sharp changes of illumination.

ANALYSIS OF CONDITIONS AND NATURE OF SUBWAY TRAIN DRIVERS' LABOUR

Dumka I.V.

SE "Ukrainian Medical Center for Traffic Safety and Information Technologies, Ministry of Public Health of Ukraine", Kyiv

The issues of the unfavorable factors' impact of working environment on the organisms of subway train drivers are presented in the article. The main unfavorable occupational factors are noise and vibration, nervous-and-emotional overstrain, stresses, forced labor posture, hypodynamia, unfavorable microclimate, total or partial lack of
These factors most reliably lead to the disruption of the mechanisms of adaptation and formation of pathological abnormalities in subway train drivers. Morbidity of the subway train drivers needs further study and solution of the issues of the improvement of working conditions, development of preventive measures and correction of revealed pathological abnormalities and diseases of the internal organs.

\section{Keywords: subway electric train drivers, hazardous conditions of work, pathological processes.}

да, їхніми конструктивними особливостями, режимом руху тощо. У даному випадку МЕП зазнають впливу загальної вібрації, що передається через нижні кінцівки і плечовий пояс $[6,16]$.

У кабінах сучасних локомотивів рівні шуму в октавних смугах на середньо-геометричних частотах 63-4000 Гц перевищують допустимі на 10-15 дБ, а періодичні перевищення гранично допустимих рівнів - на 16-26 дБ [17]. Як свідчать результати досліджень, частота коливань змінюється від 1,3 Гц до 4 Гц. Рівень вібрації у кабіні машиніста перевищує допустимі норми у 214 разів за вертикальною складовою і в 1,1-10 разів - за горизонтальною віссю [18-19].

Особливу увагу слід приділити стресовому фактору. МЕП постійно перебувають під впливом професійного стресу. Гострі стреси виникають під час наїздів або їх можливості.

Оцінка впливу чинників трудового процесу на машиністів МЕП за критеріями ГКТ № 4137-86 [1] дозволяє віднести їхню працю до напруженої. Робоче місце МЕП згідно 3 наказом МО3 України № 528 від 27.12.2001 р. «Про затвердження гігієнічної класифікації праці за показниками шкідливості та небезпечності факторів виробничого середовища, важкості та напруженості трудового процесу» слід вважати з важкими та шкідливими умовами праці, що має 4 фактори 1 ступеня (шум, вібрація, неіонізуюче випромінювання, режим праці) і 2 фактори 2 ступеня (важкість праці за фактором «робоча поза», напруженість праці за фактором «емоційна та інтелектуальна напруженість»).

Усе вищезгадане у поєднанні 3 впливом інших виробничих факторів (вібрація, мікроклімат, повна або часткова відсутність природної освітленості, перепади освітленості, різка зміна штучної та природної освітленості) сприяє розвитку функціо- нальної перенапруги організму, хронічного стомлення, прискоренню темпів біологічного старіння, розвитку захворювань 3 тимчасовою втратою працездатності й професійно зумовленої патології. За літературними даними зроблено висновок, що в усіх вікових групах МЕП відзначається перевищення біологічного віку над паспортним [20]. Тривалі інформаційні професійні перевантаження, особливо в умовах гіподинамії, висока відповідальність за життя багатьох людей можуть призводити до формування таких станів, як хронічний стрес, хронічна втома, неврози, професійне "вигоряння" й інші, які, у свою чергу, провокують загострення хронічних захворювань або стимулюють появу раніше відсутньої патології [21].

у МЕП зустрічаються певні загальносоматичні патології та професійні захворювання, які виникають під дією несприятливих виробничих факторів. Перші ознаки зниження професійної працездатності у МЕП спостерігаються після 45 років при стажі роботи більше 21 року. Стаж, при якому ризик розвитку профзахворювань $€$ найвищим, становить за дії вібрації 10 років, виробничого шуму - 14 років. Зниження слуху відзначено у МЕП у віці 35 років при стажі 12 років. Акомодаційна здатність ока зберігається на високому рівні у МЕП до 40 років при стажі до 15 років. Далі відбувається значне зниження цього показника у 93\% машиністів. Істотне погіршення функціонального стану ССС спостерігається у віці 47 років при стажі роботи 26 років. Розвиток хронічних захворювань у МЕП дослідники відзначили вже у віці 16-19 років. Це переважно хвороби органів дихання. У віковому інтервалі 2024 роки питома вага сформованих хронічних захворювань збільшилася у 6,9 разів і склала 10,4\%. У віковому інтервалі 35-
54 роки відзначали незначне зростання хронічних захворювань і зниження їх у віці 55-60 і більше років [25].

При вивченні захворюваності МЕП виявлено, що вони хворіють у 10 разів частіше, ніж представники основних професій інших видів діяльності і у 2-3 рази частіше, ніж інші спеціалісти метрополітену. За даними літературних джерел, взаємозв'язок захворюваності з професійними факторами дуже високий. Так, доведено, що професії високонапруженої праці (зокрема операторської), які характеризуються переробкою значної кількості інформації, особливо в умовах дефіциту часу, можуть істотно впливати на функціональний стан та здоров'я працівників, сприяти розвитку передпатологічних станів перенапруження, перевтоми, зростанню захворюваності [3, 15, 22-24]. Професії 3 високою напруженістю праці за захворюваністю посідають перше місце серед інших професій [15].

Необхідно зазначити, що більшість хвороб досить просто діагностується рутинними методами досліджень і легко розпізнається фахівцями. Це хвороби органів зору, кістково-м'язової системи, органів слуху та інші. Вони не ускладнюються станами, які можуть призвести до раптової недієспроможності машиніста. Деякі хвороби, навпаки, досить часто можуть супроводжуватися розвитком ускладнень, що серйозно впливають на дієспроможність працівника. Наприклад, гострі порушення серцевого ритму, гострий інфаркт міокарда, гострі порушення мозкового кровообігу, напади епілепсії та інші пароксизмальні стани можуть зумовити раптове вимикання свідомості чи навіть раптову смерть. Ці стани, якщо вони виникають безпосередньо під час керування електропоїздом, легко можуть призвести до катастрофічних наслідків і становлять реальну 
загрозу безпеці руху метрополітену. Своєчасна діагностика хвороб, які можуть супроводжуватися такими станами, прогнозування цих ускладнень та їх профілактика є найважливішим специфічним завданням залізничної медицини. Певною мірою ці питання розв'язуються під час диспансерного спостереження за працівниками та проведення заходів вторинної профілактики. Підвищена увага у лікувальних закладах приділяється хворим з патологіями серцево-судинної системи. Дещо зросла їхня питома вага у структурі диспансерної групи, але цей напрямок роботи ще потребує подальшого удосконалення. На Укрзалізниці ще й досі відсутня цілеспрямована система психофізіологічного обстеження осіб, робота яких пов'язана з безпекою руху на залізничному транспорті. Реалізація цих заходів, безумовно, сприятиме підвищенню надійності "людського фактора" та значному зниженню ймовірності надзвичайних ситуацій на залізничному транспорті.

Отже, для забезпечення трудового довголіття МЕП найголовніше - це зберегти і зміцнити здоров'я, вчасно розпізнати ризик виникнення хвороби запобігти їй. Саме тому необхідне подальше вивчення зв'язку виникнення захворювань МЕП з умовами праці, розробка методів покращання цих умов та зміцнення здоров'я цієї категорії працівників.

Висновки

1. Робота МЕП є однією з найвідповідальніших серед багатьох професій. Це пов'язане з тим, що працівники даної категорії забезпечують безпеку руху електропоїздів метрополітену, несуть відповідальність за життя великої кількості пасажирів. У процесі своєї діяльності МЕП зазнають постійної дії шкідливих виробничих чинників: позмінної праці, високої нервово-емоційної напруги, зумовленої особистою відповідальністю за забезпечення безпеки руху і готовністю до швидких координованих дій в екстремальних ситуаціях тощо.

2. Збільшення частоти хронічних захворювань зростає 3 віком, особливо при стажі роботи понад 20 років, що пов'язано 3 впливом на МЕП виробничих факторів і стресу. Відзначається, що зі збільшенням стажу роботи простежувалася достовірна тенденція $(p<0,05)$ до перенапруження активності систем регуляції у МЕП. Отримані результати показали, що зі збільшенням стажу роботи збільшувалася кількість осіб, що мали порушен- ня процесів регуляції активності регуляторних систем, причому найбільше зростання відзначене у групі МЕП - у 5 разів.

3. Згідно з даними літератури, високий рівень захворюваност машиністів поїздів великою мірою пов'язаний 3 шкідливим впливом виробничих чинників.

ЛІТЕРАТУРА

1. Захаренко М.И., Палийчук С.П., Мартиросова В.Г., Городецкая Л.П. Условия труда машинистов электропоездов метрополитена, особенности изучения и оценки. Актуальные проблемы транспортной медицины. 2005. № 2. С. 56-59.

2. Палійчук С.П. Особливості умов праці машиністів електропоїздів метрополітену і атестація робочих місць. Гігієнічна наука та практика на рубежі століть: матеріали XIV з'їзду гігієністів України. Дніпропетровськ, 2004. T. 2. С. 66-67.

3. Палийчук С.П., Захаренко М.И., Мартиросова В.Г., Городецкая Л.П. Условия труда машинистов электропоездов метрополитена, особенности изучения и оценки. Актуальные проблемы транспортной медицины. 2005. № 2. С. 56-59.

4. Орехов В.О. Психофизиологические показатели, обеспечивающие безопасную работу локомотивных бригад. Пермский медицинский журнал. 2003. № 1. С. 106-109.

5. Маслюк В.В., Антомонов М.Ю. Психофізіологічні критерії збереження професійного здоров'я машиністів локомотивів. Київ, 2013. Режим доступу : http://lib.exdat.com/docs/9061/in dex-7860-1.html.

6. Жижневская А.А., Лисобей В.А. О взаимосвязи заболеваемости машинистов железнодорожного транспорта и их помощников с условиями труда. Актуальные проблемы транспортной медицины. 2006. № 3 (5). C. 69-73.

7. Лисобей В.А. Заболеваемость работников транспорта. Одесса : Черноморье, 2005. 262 с.

8. Лисобей В.А. Взаимодействие санитарно-эпидемиологической и лечебно-профилактической служб - основа внедрения обязательной государственной бюджетно-страховой медицины на транспорте. Актуальные проблемы транспортной медицины. 2007. № 2 (8). C. 30-39.

9. Ткачишин В.С., Арустамян О.М., Ткачишина Н.Ю., Каневський О.С. Загальносоматична та професійна патологія серед працівників локомотивних бригад. Медицина транспорту України. 2011. № 1 (37). С. 99-107.

10. Піддубна Т.П., Бороденко Л.С. Гігієнічна оцінка умов праці та відпочинку робітників локомотивних депо Південної залізниці та аналіз захворюваності з тимчасовою втратою працездатності. Режим доступу : http://www.dorses.Iviv.ua/CONFER/2004-virtual/ articles/PZ\% 20-\%20loc\%20brig.html.

11. Гнетило С.С., Бурдейна Н.О., Данюк Л.Д., Пілка О.Д., Долгош М.Ю. Оцінка стану здоров'я залізничників, робота яких пов'язана з безпекою руху поїздів. Медицина транспорту України. 2012. № 2. С. 66-69.

12. Балабан С.В., Боднарь В.П., Панов Б.В., Свирский А.А., Матвеев А.Г. Актуальные проблемы заболеваемости на железнодорожном транспорте. Актуальні проблеми транспортної медицини. 2014. № 1 (35). С. 105-110.

13. Диба С.А., Остапчук В.М., Тубольцев О.М., Кочуєв Г.І. Аналіз стану здоров'я осіб, працюючих на посадах, пов'язаних з безпекою руху на залізничному транспорті, та заходи щодо поліпшення медичних аспектів професійного добору на Укрзалізниці. Актуальні проблеми транспортної медицини. 2002. № 1 (3). С. 18-20.

14. Касьянов Н.А., Пительгузов Н.А., Маслов В.А., Гундарь В.П. Комплексная оценка условий труда в кабинах машинистов подвижного состава производства ХК «Лугансктепловоз». Вісник Східноукраїнського нац. ун-ту ім. В. Даля. 2010. № 3 (145). C. 5-10.

15. Березов В.М., Попов А.А., Грицкевич О.С. К вопросу экспертизы медицинской профпригодности у железнодорожников. Актуальные вопросы железнодорожной медицины: матер. конф. М., 2003. № 6. С. 38-39.

16. Панкова В.Б., Синева Е.Л., Федина И.Н. Заболевания лимфоглоточного кольца у работников «пылевых» производств.

Вестник оториноларингологии. 2013. № 3. С. 35-38.

17. Панкова В.Б. Профессиональная тугоухость у работников железнодорожного транспорта. Вестник оториноларингологии. 2009. № 6. С. 14-18.

18. Ткач Л.А., Рыженко С.А., Лысый А.Е., Вайнер Е.П., Грузин И.И., Шевченко А.А. и др. Гигиеническая оценка условий труда профессиональной заболеваемости машинистов тепловозов железнодорожного цеха. Актуальные проблемы транспортной медицины. 2010. № 2 
(20). C. 25-31.

19. Захаренко М.И., Липовой В.В., Палийчук С.П. и др. Особенности условий труда членов локомотивных бригад и их влияние на профессиональное здоровье. Гігієна та практика на рубежі століть: матеріали XIV з'їзду гігієністів України. Дніпропетровськ, 2004. С. 67-69.

20. Панкова В.Б., Иванов В.К., Кутовой В.С. Медико-социальные аспекты снижения риска развития профессиональных заболеваний и производственного травматизма на железнодорожном транспорте. Гигиена и санитария. 2001. № 6. С. 33-37.

21. Пишнов Г.Ю., Палійчук С.П., Висоцька Л.Г. Особливості і порівняльна оцінка розвитку синдрому “вигорання" у професійних групах напруженої праці. Довкілля та здоров'я. 2007. № 2. С. 51-55.

22. Апихтін К.О. Особливості вегетативної регуляції серцевосудинної системи в осіб з синдромом хронічної втоми. Український журнал з проблем медицини праці. 2005. № 1. С. 33-37.

23. Коркушко О.В., Шатило В.Б., Писарук А.В., Чеботарев Н.Д., Лишневская В.Ю. Методы анализа и возрастные нормы вариабельности ритма сердца (метод. рек.). Київ : Науковий світ, 2003. 21 с.

24. Ковалева А.И., Чернюк В.И., Ластовченко В.Б., Пишнов Г.Ю., Назаренко В.И. Физиологогигиеническая оценка характера и условий труда диспетчеров по управлению воздушным движением. Гигиена труда : сб. науч. тр. К., 2004. Вып. 35. С. 66-67.

25. Пешкова В.Б., Иванов В.К., Кутовой В.С. Медико-социальные аспекты снижения риска развития профессиональных заболеваний и производственного травматизма на железнодорожном транспорте. Гигиена и санитария. 2001. № 6. С. 33-37.

REFERENCES

1. Zakharenko M.I., Paliichuk S.P., Martirosova V.G. and Gorodetskaya L.P. Aktualnye problemy transportnoy meditsiny. 2005 ; 2 : 5659 (in Russian).

2. Paliichuk S.P. Osoblyvosti umov pratsi mashynistiv elektropoizdiv metropolitenu I atestatsiia robochykh mists [Features of the Working Conditions of Underground Train Drivers and Certification of Workplaces]. In : Hihiienichna nauka ta praktyka na rubezhi stolitt : materialy XIV zizdu hihiienistiv Ukrainy [Hygienic Science and Practice at the Turn of the Century: Materials of XIV Congress of the Hygienists of Ukraine] Dnipropetrovsk ; 2004 ; 2 : 66-67 (in Ukrainian).
3. Paliichuk S.P., Zakharenko M.I., Martirosova V.G. and Gorodetskaya L.P. Aktualnyie problemy transportnoy mediziny. $2005 ; 2$ : 56-59 (in Russian).

4. Orekhov V.O. Permskiy meditsinskiy zhurnal. 2003 ; 1 : 106109 (in Russian).

5. Masliuk V.V. and Antomonov M.Yu. Psykhofiziolohichni kryterii zberezhennia profesiinoho zdorovia mashynistiv lokomotyviv [Psychophysiological Criteria of the Preservation of the Professional Health of Locomotive Drivers]. Kyiv ; 2013. Available at : http:// lib.exdat.com/docs/9061/index7860-1.html (in Ukrainian).

6. Zhizhnevskaya A.A. and Lisobey V.A. Aktualnyie problemy transportnoy mediziny. 2006 ; 3 (5) : 69-73 (in Russian).

7. Lisobey V.A. Zabolevaiemost rabotnikov transporta [Morbidity of Transport Workers]. Odessa : Chernomorye ; 2005 : 262 p. (in Russian).

8. Lisobey V.A. Aktualnyie problemy transportnoy mediziny. 2007 ; 2 (8) : 30-39 (in Russian).

9. Tkachyshyn V.S.

Arustamian O.M., Tkachyshyna N.Yu. and Kanevskyi O.S. Medytsyna transportu Ukrainy. 2011; 1 (37) : 99-107 (in

Ukrainian).

10. Piddubna T.P. and Borodenko L.S. Hihiienichna ozinka umov pratsi ta vidpochynku robitnykiv lokomotyvnoho depo Pivdennoi zaliznyzi ta analiz zakhvoriuvanosti z tymchasovoiu vtratoiu pratsezdatnosti [Hygienic Assessment of Working Conditions and Rest of the Workers of the Southern Railway Locomotive Depot and Analysis of Morbidity with Temporary Disability]. Available at: http: //www.dorses.Iviv.ua/CONFER/ 2004-virtual/_articles/PZ\%20\%20loc\%20brig.html

(in Ukrainian).

11. Gnetylo S.S., Burdeina N.O., Daniuk L.D., Pilka O,D. and Dolhosh M.Yu. Medytsyna transportu Ukrainy. 2012 ; 2 : 66-69 (in Ukrainian).

12. Balaban S.C., Bodnar V.P. Panov B.V., Svirskiy A.A. and Matveiev A.G. Aktualni problemy transportnoi medyzyny. 2014 ; 1 (35) : 105-110 (in Russian).

13. Dyba S.S., Ostapchuk V.M., Tuboltsev O.M. and Kochuiev G.I. Aktualni problemy transportnoi medyzyny. $2002 ; 1$ (3):18-20

(in Ukrainian).

14. Kasianov N.A., Pitelguzov N.A., Maslov V.A. and Gundar V.P. Visnyk Skhidnoukrainskohonatsionslnoho universytetu im. V. Dalia. 2010 ; 3 (145) : 5-10 (in Russian).

15. Berezov V.M., Popov A.A. and Grizkevich O.C. K voprosu ekspertizy meditsynskoy profprigodnosti u zheleznodorozhnikov [On the Issue of the Examination of Medical Suitability in Railroders]. Aktualnye voprosy zheleznodorozhnoy mediziny: mater. konf. [Actual Issues of Railroad Medicine: Mater. Conf.]. Moscow ; 2003 ; 6 : 38-39 (in Russian).

16. Pankova V.B., Sineva Ye.L. and Fedina I.N. Vestnik otorinolaringologii. 2013 ; 3 : 35-38 (in Russian).

17. Pankova V.B. Vestnik otorinolaringologii. 2009 ; 6 :14-18

(in Russian).

18. Tkach L.A., Ryzhenko C.A., Lysyi A.Ye.,Vainer Ye.P., Gruzin I.I., Shevchenko A.A. et al. Aktualni problem transportnoi medyzyny. 2010 ; 2 (20) : 25-31 (in Russian).

19. Zakharenko M.I., Lipovoi V.V., Paliychuk S.P. et al. Osobennosti usloviy truda chlenov lokomotivnykh brigad I ikh vliyanie na professionalnoye zdorovie [Peculiarities of Working Conditions of the Members of Locomotive Brigades and Their Impact on the Occupational Health]. In : Higiiena ta praktyka na rubezhi stolit : materialy XIV zizdu hihiienistiv Ukrainy [Hygiene and Practice at the Turn of the Century: Materials of XIV Congress of the Hygienists of Ukraine]. Dnipropetrovsk ; 2004 : 67-69 (in Russian).

20. PankovaV.B., Ivanova V.K. and Kutovoy V.S. Gigiiena i sanitaria. 2001; 6 : 33-37 (in Russian).

21. Pyshnov G.Yu., Paliichuk S.P. and Vysotska L.G. Dovkillia ta zdorovia. $2007 ; 2: 51-55$ (in Ukrainian).

22. Apykhtin K.O. Ukrainskyi zhurnal z problem medytsyny pratsi. 2005 ; 1 : 33-37 (in Ukrainian).

23. Korkushko O.V., Shatylo V.B., Pysaruk A.V., Chebotarev N.D. and Lishnevskaya V.Yu. Metody analiza i vozrastnye normy variabelnosti ritma serdtsa [Methods of Analysis and Age Standards of Variabilityof Heart Rhythm (Methodical Recommendations)]. Kyiv : Naukovyi svit ; 2003 : 21 p. (in Russian).

24. Kovaleva A.I., Cherniuk V.I., Lastovchenko V.B., Pyshnov G.Yu. and Nazarenko V.I. Fiziologogigiyenicheskaya ozenka kharaktera i usloviy truda dispetcherov po upravleniyu vozdushnym dvizheniyem [Physiological-andHygienic Assessment of Character and Working Conditions of Air Traffic Control Officers]. In : Gigiiena truda: [Working Hygiene : Coll. Sci.Works]. Kiev ; 2004 ; 35 : 66-67 (in Russian).

25. Peshkov V.B., Ivanov V.K. and Kutovoy V.S. Gigiiena $i$ sanitaria. $2001 ; 6$ : 33-37 (in Russian).

Надійшла до редакції 24.11.2016 